\title{
Kvalitatív lONGITUdinÁlis VIZSGÁLAT A SZEGEDI TUDOMÁNYEGYETEM KÜLFÖLDI HALLGATÓINAK ELÉGEDETTSÉGÉRŐL ÉS LOJALITÁSÁRÓL
}

\author{
KÉRI ANITA \\ Szegedi Tudományegyetem, Gazdaságtudományi Kar \\ Beérkezett: 2021. február 14., elfogadva: 2021. november 3.
}

\begin{abstract}
A felsőoktatás nemzetköziesedése régóta foglalkoztatja a hazai kutatókat, így a külföldi hallgatók véleményének és a magyar felsőoktatás által nyújtott képzésminőségnek a vizsgálata igencsak kiterjedt. Jelen tanulmány célja, hogy a külföldi hallgatók elvárásainak és elégedettségének változásait, valamint lojalitását vizsgálja egy három éven keresztül tartó longitudinális mélyinterjúsorozat segítségével. A paneles kvalitatív kutatás eredményei azt mutatják, hogy a vizsgált hallgatók elvárásai és elégedettsége is változik az idő előrehaladtával és a képzés végének közeledtével, lojalitásuk pedig nem csupán az egyetemmel kapcsolatosan, de a külföldi tanulási élménnyel kapcsolatosan is kialakulhat.
\end{abstract}

Kulcsszavak: felsőoktatás, nemzetköziesedés, elvárások, elégedettség, lojalitás

The internationalization of higher education has long been at the centre of research interest. Therefore, the opinion of foreign students and the study of Hungarian higher education institutions' service quality are researched widely. The aim of the current study is to shed light on the changes in foreign student expectations and satisfaction and to examine their loyalty with a longitudinal panel interview series over three years. Research results show that foreign student expectations and satisfaction change with time and loyalty can appear towards the institution and the foreign study experience, too.

Keywords: higher education, internationalization, expectations, satisfaction, loyalty

Levelező szerző: Dr. Kéri Anita, Szegedi Tudományegyetem, Gazdaságtudományi Kar, 6722 Szeged, Kálvária sgt.1.E-mail: keri.anita@eco.u-szeged.hu 


\section{Bevezetés}

$\mathrm{A}^{2}$ külföldi hallgatók elvárásainak, elégedettségének és lojalitásának, valamint képzési minőségének vizsgálata a felsőoktatás nemzetköziesedésének erősödésével egyre központibb kutatási témává vált az utóbbi évtizedekben. Habár a témát illetően széles nemzetközi és magyar szakirodalom áll rendelkezésre, mégis szükös azon forrásoknak a köre, melyek kvalitatív módszertanra támaszkodva igyekeznek megismerni a külföldi hallgatókat (Sultan-Wong 2013; Gallarza-Seric-Cuadrado 2017). Még ennél is elenyészőbb azoknak a longitudinális kvalitatív vizsgálatoknak a száma, melyek a külföldi hallgatók elvárásaival és elégedettségével foglalkoznak (Patterson-Romm-Hill 1998). Holott a kvalitatív módszerek szélesebb körben történő alkalmazása mélyebb betekintést tesz lehetővé a külföldi hallgatók elvárásaiba, elégedettségébe és lojalitásába is.

Jelen tanulmány egy három éven keresztül folytatott, mélyinterjúkon alapuló paneles vizsgálat eredményeit mutatja be. A kutatás célja, hogy feltárja, hogyan változnak a külföldi hallgatók elvárásai és elégedettsége, valamint kialakul-e a képzés időtartama alatt a lojalitás. A tanulmány továbbá célul tűzi ki a külföldi hallgatók elégedettségét és lojalitását befolyásoló fontosabb tényezők feltárását is.

\section{A kvalitatív kutatás előzetes feltételezései}

A valamivel szembeni általános elvárásokat többnyire az elégedettséggel kutatják együtt, és megjelenhet mint befolyásoló tényező (Cardozo 1965), mint szubjektív összehasonlítási alap (Miller 1977; Oliver 1999), mint előrejelző tényező (Churchill-Suprenant 1982) és mint tanulási folyamat eredménye (Woodruff-Cadotte-Jenkins 1983) is. Az elvárások fogalmának felsőoktatásban történő meghatározása is nehézkes a szolgáltatásjelleg és az elözetes tapasztalat hiánya miatt (Gerdes-Mallinckrodt 1994). Jelen kutatásban a hallgatói elvárásokra mint felidézett várakozásokra tekintek, melyek a külföldön való tanulással kapcsolatosak, és melyek egyaránt lehetnek tiszta vagy zavaros elvárások (Ojasalo 2001). Továbbá az elvárásokat Oliver (1999) diszkonfirmációs paradigmája alapján értelmezzük, mely szerint azok befolyásolják az elégedettséget is (Shahsavar-Sudzina 2017).

Az elégedettség fogalmát többnyire az elvárások és a tapasztalatok szubjektív összehasonlításaként értelmezik (Cardozo 1965; Oliver 1999), mely értelmezés a felsőoktatási kutatásokban is mérvadó (Chui et al. 2016). A kutatás során a külföldi hallgatók elégedettségét úgy értelmezzük, amely az elvárások és tapasztalatok szubjektív összevetését mutatja, s amely a nemzetközi hallgatók külföldön töltött tanulmányainak teljes folyamatára vonatkozik, és a fogyasztással egy időben vagy az után értelmezhető. A fogalmak szoros összefonódása miatt összefüggés feltételezhető a külföldi hallgatók elvárásai és elégedettsége között (Owlia-Aspinwall 1996; Elliot-Healy 2001; Alves-Raposo 2009).

$\mathrm{Az}$ elégedettség kapcsán nehézséget jelent az elégedettséget befolyásoló tényezők csoportosítása. Korábbi kutatásokban számos olyan befolyásoló tényező szerepel, mely az egyetemhez köthető, de nem kapcsolható kimondottan az oktatási szolgáltatáshoz (pl. adminisztratív folyamatok, infrastruktúra, épületek modernitása). Szintén előfordul, hogy az egyetem kilép a falai közül (pl. egyetemi rendezvények az egyetem épületein kívül) vagy invitálja a külvilágot az egyetemre (pl. céges előadások egyetemistáknak). 
Jelen kutatásban az egyetemmel kapcsolatos elégedettséget befolyásoló tényezőket az oktatással kapcsolatos, valamint a nem oktatási szolgáltatáshoz köthető, de egyetemmel kapcsolatos faktorok együtteseként határoztuk meg. Hozzátéve, hogy a nem kimondottan az intézményhez és annak várható teljesítményéhez kapcsolható elégedettségre úgy tekintünk, melyre az intézménynek nincsen közvetlen ráhatása.

Korábbi kutatásokban látható, hogy a lojalitást szinte mindig együttesen vizsgálják az elégedettséggel, és kapcsolatot feltételeznek a kettő között, hiszen az elégedettség sok esetben hatást gyakorol a lojalitásra (Gronholdt-Martensen-Kristensen 2000; AlvesRaposo 2009; Giner-Rillo 2016). Jelen kutatásban azt is próbáljuk feltárni, hogy ez a kapcsolat létezik-e a kiválasztott felsőoktatási intézmény külföldi hallgatóinak elégedettsége és lojalitása között.

Számos kutatás próbálkozott már felderíteni és megmagyarázni a külföldi hallgatók lojalitását a felsőoktatási intézmény felé, melyekben közös tényezőként a lojalitás definíciójának komplex megközelítését fedezhetjük fel (Alves-Raposo 2009; Giner-Rillo 2016). Néhány kutató bizonyos tényezőket definiál, melyek amennyiben kielégítésre kerülnek, lojalitáshoz vezethetnek (Schertzer-Schertzer 2004), míg vannak kutatók, akik azt vizsgálják, hogy miként jelenik meg a lojalitás külföldi hallgatói szájreklámok útján (AlvesRaposo 2009). Kevés kutatásban vizsgálták kvalitatív módon, hogy mit jelent a lojalitás a hallgatók számára, de az ilyen típusú eddigi vizsgálatok azt bizonyítják, hogy hallgatónként eltérő lehet a lojalitás értelmezése (Sultan-Wong 2013; Gallarza-Seric-Cuadrado 2017).

Mindezekből következően a kutatásban az alábbi öt előfeltevés fogalmazható meg:

E1: A külföldi hallgatókban csak zavaros elvárások fogalmazódnak meg a külföldi tanulással kapcsolatosan.

E2: A külföldi hallgatói elvárások és a hallgatók elégedettsége között összefüggés fedezhető fel.

E3: A hallgatók elégedettségét tekintve különbség tehető a felsőoktatási intézményhez szorosan és az ahhoz szorosan nem kapcsolódó tényezők között.

E4: Az elégedettség és lojalitás fogalma szorosan összekapcsolódik, és együttesen vizsgálható külföldi hallgatókkal kapcsolatos kutatások esetén.

E5: A külföldi hallgatók lojalitása sokrétű, és annak egyik lehetséges kifejező tényezője a pozitív szájreklám.

\section{A kutatás módszertana}

A kutatásban mélyinterjúk segítségével vizsgáltuk a külföldi hallgatók véleményét, mely adatgyüjtési módszer lehetővé teszi a személyes vélemények mélyebb feltárását és megértését (Patterso-Romm-Hill 1998; Griner-Sobol 2014). A kutatás helyszíne a Szegedi Tudományegyetem, a vizsgálat alanyai pedig az egyetemen tanuló külföldi hallgatók. A minta kiválasztásakor a nemzetközi hallgatók lehető legnagyobb diverzifikálása volt a cél annak érdekében, hogy véleményüket származási ország, képzési szint, és egyetemi kar szerint is a legjobban megismerhessük. Ugyanakkor fontos kiemelni, hogy jelen tanulmányban azokat a hallgatókat tekintjük külföldi hallgatóknak, akik nem határmenti külföldi országból érkeztek az egyetemre. Összesen 18 Stipendium Hungaricum ösztöndíjjal rendelkező, teljes képzésre érkező reguláris külföldi hallgató került kiválasztásra, melyből 17 fő vett részt a panelvizsgálatban (egy kiválasztott alany nem 
válaszolt a megkeresésre), akikkel összesen 51 mélyinterjú készült. Az alap-, mester- és $\mathrm{PhD}$-képzésen felül egy osztatlan orvosképzésben tanuló hallgató is bekerült az interjúalanyok közé.

A mélyinterjúk három fázisban kerültek rögzítésre, az első mélyinterjú a hallgatók képzésének elején, a második a képzésük közepén, a harmadik pedig végzés után (vagy annak közelében) készült. A strukturált mélyinterjúk első fázisában az elvárásokat, a második fázisban az elégedettséget, a harmadik és egyben utolsó fázis során pedig az elégedettséget és lojalitást vizsgáltam. A kutatás 2015 őszétől 2018 júliusának végéig tartott.

\section{A kutatás eredményei}

A z interjúk eredményeiből jól látható, hogy volt olyan hallgató, aki konkrét elvárásokkal rendelkezett, ám olyan hallgató is volt, akinek csupán általános elvárásai voltak, melyek nem kimondottan az Szegedi Tudományegyetemre, hanem a továbbtanulásra vonatkoztak, valamint olyan hallgató is akadt, akinek egyáltalán nem voltak specifikus elvárásai. Ezen eredmények egybecsengenek a korábbi vizsgálatok eredményeivel, hiszen az idegen országra és felsőoktatási intézményeire elvárásokat megfogalmazni kiváltképp nehéz (Ojasalo 2001; Gerdes-Mallinckrodt 1994). Elmondható az is, hogy a képzési szinttől függően változnak a hallgatói elvárások, az egyre magasabb képzési szintek felé (mester, $\mathrm{PhD}$ ) haladva egyre konkrétabb elvárásokkal találkozhatunk. Míg alapképzés során az egyetemmel kapcsolatos és az egyetemhez szorosan nem kapcsolható elvárásokat is találunk, a mesterképzéses, illetve a $\mathrm{PhD}$-hallgatók esetén az elvárások túlnyomó többsége már konkrét kutatásokra és az intézmény által biztosított lehetőségekre vonatkozik.

„Miután végzek, lehet, hogy elvégzem a mesterképzést." (kazahsztáni hallgató)

„Azt várom, hogy egy jó minöségü diplomám lesz, jó tapasztalatokkal, és a diplomát Európában is elfogadják." (namibiai hallgató)

"Érdekel a PhD. Szeretnék oktatói vagy docensi karriert." (kolumbiai hallgató)

Összességében tehát elmondható, hogy a külföldi hallgatókban nemcsak zavaros elvárások fogalmazódnak meg a külföldi tanulás kapcsán (E1), hanem konkrét elvárások is, mely nagyban függ a képzési szinttől is. A kutatás második és harmadik szakaszában feltett kérdésekre adott válaszok alapján a hallgatói elvárások és a hallgatói elégedettség között tapasztalható összefüggés (E2), azonban a hallgatók egy részének elégedettsége nagymértékben függött attól, hogy elvárásaik milyen mértékben teljesültek.

„Nem azt kaptam, amit vártam, banem annál sokkal többet." (indiai ballgató)

"Azt hiszem, az elvárásaim változtak abhoz képest, mint mikor idejöttem." (vietnami hallgató)

Ugyanakkor ennek kapcsán további kutatást igényel az a kérdés, hogy azoknál a hallgatóknál, akik nem rendelkeztek korábban specifikus elvárásokkal, mi alapján történhet az elégedettség meghatározása.

A mélyinterjúk elemzésének eredményei alapján egyértelműen látszik, hogy az elégedettség - vagy éppen elégedetlenség - nem csupán az egyetemhez szorosan köthető tényezőkkel szemben áll fenn, hanem egyéb olyan szempontokhoz is kapcsolódhat, melyekre az egyetemnek nincsen közvetlen hatása (E3). Vagyis külön-külön is vizsgálható az egyetemhez kapcsolódó és az egyetemhez szorosan nem kapcsolódó tényezőkkel való elégedettség (Schertzer-Schertzer 2004; Sultan-Wong 2013).

"Jó város (Szeged), de egy kicsit unalmas." (tunéziai ballgató) 
„Nem tudok konferenciákra és workshopokra menni, mert mind magyarul vannak.” (indiai ballgató)

$\mathrm{A} z$ elégedettség kapcsán a hallgatók konkrét rákérdezés nélkül is említettek olyan tényezőket, melyek a lojalitáshoz köthetők (E4), ilyenek voltak többek között a továbbajánlás és a hallgatók újraválasztási hajlandósága (vö. Gronholdt-Martensen-Kristensen 2000; Giner-Rillo 2016).

„Annyira elégedett vagyok, hogy már ajánlottam is (másoknak), és ott van az élö példa (eközben egy hallgatótársára mutat az iroda másik felében)." (namíbiai ballgató)

A hallgatók válaszai alapján is arra következtethetünk, hogy a lojalitás fogalma valóban összetett a felsőoktatásban (Giner-Rillo 2016), ám a pontos definiálásra nem történtek még kísérletek. A legtöbb kutatásban a különböző tényezőkkel való elégedettséget tekintik a lojalitás fó indikátorának (Schertzer-Schertzer 2004). A felsőoktatásban megjelenő lojalitásdefiníció hiányának oka az lehet, hogy az igen sokrétű, melyet alátámasztanak a mélyinterjúk eredményei is. A megkérdezett hallgatók más és más tényezőt tekintettek a lojalitás ismérvének (E5), mint például a tradíciók tisztelete, a reciprocitás, a büszkeség, a szomorú búcsúvétel vagy a munkahelyi kapcsolatok. A különbségek ellenére sok hasonlóságot is sikerült felfedni, mint például az érzelmi kötődést, Szeged otthonnal való azonosítását, a pozitív szájreklámot és az újraválasztásra való hajlandóságot. A 17 interjúalany közül 12 egészen biztosan újraválasztaná, 16 pedig továbbajánlaná a Szegeden való tanulást.

"A lojalitás a tradiciók tiszteletét jelenti ..." (kolumbiai hallgató)

"A lojalitásom azt jelenti, hogy bármikor támogatom az egyetemet és Magyarországot, ami a második otthonom." (koreai hallgató)

„Számomra a lojalitás azt jelenti, hogy más embereknek reklámozom az egyetemet..." (laoszi hallgató)

Az eredmények alátámasztották azt is, hogy a pozitív szájreklámot a hallgatók a lojalitást kifejező tényezőként értelmezik (E5) (vö. Alves-Raposo 2009).

A kvalitatív kutatásban vizsgált tényezők időbeli változására reflektálva elmondható, hogy az elvárások és elégedettség tekintetében az alapképzéses hallgatók esetén jobban különváltak az egyetemmel kapcsolatos és az ahhoz szorosan nem kapcsolódó tényezők a kutatás utolsó szakaszában, mint a második szakaszban. Ez a tendencia a mesterképzéses hallgatóknál nem volt megfigyelhető, mely többek között adódhat a képzés rövidebb időtartamából is. Az alapképzéses hallgatók a kutatás harmadik szakaszában több olyan tényezőt említenek, melyre az egyetemnek nincsen közvetlen hatása, mint például a barátok vagy Szeged város elhelyezkedése és adottságai. A mesterképzéses hallgatók esetén az elégedettség kapcsán a második és harmadik szakasz során is leginkább az egyetemmel kapcsolatos tényezők jelentek meg hangsúlyosan, és érdekes módon inkább a második szakaszra volt jellemző az egyetemen kívüli tényezők említése. $\mathrm{A} \mathrm{PhD}$-képzésben részt vevő hallgatók saját elmondása szerint is változtak saját elvárásaik és elégedettségük a Szegeden töltött idő alatt, hiszen ez a fejlődésük egyik velejárója. Emellett a $\mathrm{PhD}$-hallgatók esetén rajzolódott ki az is, hogy amíg a második szakaszban leginkább az oktatókról és a kurzusokról beszéltek az elégedettség kapcsán, a harmadik szakasz során már a tanulmányaikhoz füződő érzelmi kötődés, a tanulás élvezete, a Szegeden töltött minőségi idő, a barátok és a jó emlékek merültek fel. 


\section{Összegzés}

A longitudinális paneles kutatás eredményei alapján látható, hogy nem minden hallgató tudja pontosan, hogy mit vár az egyetemtől, nem mindenkinek vannak pontos elvárásai, ám ez a képzési szinttől függ leginkább, hiszen a mester- és $\mathrm{PhD}$-képzésben részt vevő hallgatóknak sokkal konkrétabb és az iskolához szorosabban kötődő elvárásai voltak, mint alapszakos társaiknak.

Az elégedettséget két részre oszthatjuk a hallgatói mélyinterjúk alapján, az egyetemmel kapcsolatos és az egyetemhez nem szorosan kapcsolódó tényezőkkel való elégedettségre. Az elégedettség tekintetében az elvárásokon alapuló teória jó kiindulópont lehet a külföldi hallgatók tanulmányozásában, miszerint, ha elvárásaik teljesültek, akkor az elégedettséghez vezethet, ami pozitív szájreklámot eredményezhet, mely szájreklám néhány hallgató számára lojalitást jelenthet. Amennyiben nem teljesülnek az elvárások, az pedig negatív szájreklámhoz vezethet.

A lojalitás kapcsán fontos megjegyezni, hogy a felsőoktatási szolgáltatás sajátosságai miatt a hallgatók körében akkor léphet fel a felsőoktatás, mint szolgáltatás újbóli igénybevétele, ha a hallgató egy szak befejezése után az adott egyetemen kíván másik szakot elvégezni, mely feltehetőleg egy, az elsőnél rangban fentebb lévő képzés (Mesterképzés, $\mathrm{PhD}$ ). A mélyinterjúk alapján az újbóli igénybevétel és a továbbajánlás jelenléte is egyértelmủen beigazolódott, ezenfelül pedig a hallgatók számos lojalitáshoz köthető tényezőt vetettek fel (pl. tradíciók tisztelete, érzelmi kötődés, büszkeség).

A kutatás egyik fó korlátja, hogy nem tekinthető reprezentatívnak, így az eredményeink sem általánosíthatók. Torzító tényező például a panelbe bevont hallgatók finanszírozási formája, hiszen az elérési nehézségek miatt csak Stipendium Hungarcium ösztöndíjjal rendelkező hallgatók kerültek a panelbe (vagyis Erasmusos vagy önköltséges hallgató nem szerepel a mintában), mely befolyásolhatta elvárásaikat, elégedettségüket és lojalitásukat is. Kasza és Hangyál (2018) szerint a Stipendium Hungaricum ösztöndíjjal rendelkező hallgatók (preferenciái, demográfiai jellemzői stb.) hasonló tendenciákat mutatnak, mint a többi nemzetközi mobilitási trendé, ugyanakkor mégsem állíthatjuk teljes bizonyosággal, hogy egy másik hallgatói minta is ugyanezeket az eredményeket hozta volna. Mindezen korlátok ellenére a kutatásunk hozzájárulhat a hallgatói elvárások, elégedettség és lojalitás összefüggésrendszerének mélyebb megértéséhez.

\section{IRODALOM}

Alves, H. \& Raposo, M. (2009) The Measurement of the Construct Satisfaction in Higher Education. Service Industries Journal, Vol. 29. No. 2. pp. 203-218.

Cardozo, R. (1965) An Experimental Study of Customer Effort, Expectation, and Satisfaction. Journal of Marketing Research, Vol. 2. No. 3. pp. 244-249.

Chui, T. B., Ahmad, M. S., Bassim, F. A. \& Zaimi, A. (2016) Evaluation of Service Quality of Private Higher Education using Service Improvement Matrix. Procedia Social and Behavioral Sciences, Vol. 224. pp. 132-140.

Churchill, G. A. \& Surprenant, C. (1982) An Investigation into the Determinants of Customer Satisfaction. Journal of Marketing Research, Vol. 19. No. 4. pp. 491-504. 
Elliot, K. M. \& Healy, M. A. (2001) Key Factors Influencing Student Satisfaction Related to Recruitment and Retention. Journal of Marketing for Higher Education, Vol. 10. No. 4. pp. 1-11.

Gallarza, M. G., Seric, M. \& Cuadrado, M. (2017) Trading off Benefits and Costs in Higher Education: A Qualitative Research with International Incoming Students. The International Journal of Management Education, Vol. 15. No. 3. pp. 456-469.

Gerdes, H. \& Mallinckrodt, B. (1994) Emotional, Social, and Academic Adjustment of College Students: A Longitudinal Study of Retention. Journal of Counseling $\mathcal{E}$ Development, Vol. 72. No. 3. pp. 281-288.

Giner, G. R. \& Rillo, A. P. (2016) Structural Equation Modelling of Co-Creation and Its Influence on the Student's Satisfaction and Loyalty Towards University. Journal of Computational and Applied Mathematics, Vol. 291. C. pp. 257-263.

Griner J. \& Sobol A. (2014) Chinese Students' Motivations for Studying Abroad. Global Studies Journal, Vol. 7. pp. 2-14.

Gronholdt, L., Martensen, A. \& Kristensen, K. (2000) The Relationship between Customer Satisfaction and Loyalty: Cross-Industry Differences. Total Quality Management, Vol. 11. Nos 4-6. pp. 509-514.

Kasza, G. \& Hangyál, Zs. (2018) Stipendium Hungaricum Scholarship Holders' Expectations and Attitudes. Tempus Public Foundation, Budapest.

Miller, E. M. (1977) Risk, Uncertainty, and Divergence of Opinion. The Journal of Finance, Vol. 32. No. 4. pp. 1151-1168.

OJasalo, J. (2001) Managing Customer Expectations in Professional Services. Managing Service Quality: An International Journal, Vol. 11. No. 3. pp. 200-212.

Oliver, R. L. (1999) Whence Consumer Loyalty? Journal of Marketing, Vol. 63. pp. 33-44.

Owlia, M. S. \& Aspinwall, E. M. (1996) A Framework for the Dimensions of Quality in Higher Education. Quality Assurance in Education, Vol. 4. No. 2. pp. 12-20.

Patterson, P., Romm, T. \& Hill, C. (1998) Consumer Satisfaction as a Process: A Qualitative, Retrospective Longitudinal Study of Overseas Students in Australia. Journal of Professional Services Marketing, Vol. 16. No. 1. pp. 135-157.

Schertzer, C. B. \& Schertzer, S. M. B. (2004) Student Satisfaction and Retention: A Conceptual Model. Journal of Marketing for Higher Education, Vol. 14. No. 1. pp. 79-91.

Shahsavar, T. \& Sudzina, F. (2017) Student Satisfaction and Loyalty in Denmark: Application of EPSI Methodology. PLoS ONE, Vol. 12. No. 12. e0189576.

Sultan, P. \& Wong, H. Y. (2013) Antecedents and Consequences of Service Quality in a Higher Education Context: A Qualitative Research Approach. Quality Assurance in Education, Vol. 21. No. 1. pp. 70-95.

Woodruff, R., Cadotte, E. \& Jenkins, R. (1983) Modeling Consumer Satisfaction Processes Using Experience-Based Norms. Journal of Marketing Research, Vol. 20. No. 3. pp. 296-304.

A cikk a Creative Commons Attribution 4.0 International License (https://creativecommons.org/licenses/ by/4.0/) feltételei szerint publikált Open Access közlemény, melynek szellemében a cikk bármilyen médiumban szabadon felhasználható, megosztható és újraközölhető, feltéve, hogy az eredeti szerző és a közlés helye, illetve a CC License linkje és az esetlegesen végrehajtott módosítások feltüntetésre kerülnek. (SID_1) 